\title{
KORELASI ANTARA MATEMATIKA DENGAN DASAR ZAT, PANAS DAN OPTIKA PADA PROGRAM STUDI PENDIDIKAN IPA
}

\author{
Fatimatul Munawaroh \\ Program Studi Pendidikan IPA Fakultas Ilmu Pendidikan Universitas Trunojoyo Madura \\ fatimphysics@gmail.com
}

\begin{abstract}
Abstrak
Kemampuan Matematika sangat diperlukan untuk bisa memahami dan menyelesaikan persoalanpersoalan dalam Fisika. Terkait pentingnya kemampuan Matematika maka di kurikulum Program Studi Pendidikan IPA terdapat mata kuliah wajib matematika yaitu Matematika I dan II. Tujuan penelitian ini adalah untuk mengetahui korelasi antara nilai Matematika dengan nilai Dasar Zat, Panas dan Optika. Studi ini dilakukan dilakukan pada mahasiswa Program Studi Pendidikan IPA angkatan 2015/2016 semester 4 yang terdiri dari 3 kelas yaitu kelas A, B dan C. Mahasiswa terscbut sudah mengambil matakuliah Matematika I, Matematika II dan Dasar zat, Panas dan Optika. Data diperoleh dengan teknik dokumentasi. Hasil analisis menunjukkan bahwa ada korelasi yang signifikan antara nilai Matematika dan nilai Dasar zat, Panas dan Optika. Indeks korelasi antara nilai Matematika I dengan nilai Dasar zat, Panas dan Optika berturut-turut sebesar 0,52;0,34 dan 0,23 untuk kelas A, B dan C. Sedangkan indeks korelasi antara nilai Matematika II dengan nilai Dasar zat, Panas dan Optika berturut-turut sebesar 0,27; 0,34 dan 0,28 untuk kelas A, B dan C.
\end{abstract}

Kata Kunci: kemampuan Matematika, Fisika, Korelasi

\begin{abstract}
Mathematic ability is indispensable for understanding and solving problems in Physics tasks. Based on the importance of the mathematic ability, the curriculum of Natural Science Education Program consists of mathematics courses namely Mathematics I and II. The purpose of this study is to determine the correlation of learning outcomes in Mathematics dan physics courses on the topic of Basic Substance, Heat and Optics. This study was conducted on the bachelor students of Natural Science Education Program on academic year 2015/2016 consisting of 3 classes that are class A, B and $C$. Students have covered the course of Mathematics I, Mathematics II and physics. Data obtained by documentation technique. The result of the analysis shows that there is a significant correlation between the learning result of Mathematics subject and the result of physics course study. The correlation index between Mathematics I and physics is 0.52; 0.34 and 0.23 for class A, $B$ and $C$. While the correlation index between Mathematics II and physics are 0.27;0.34 and 0.28 for classes $A, B$ and $C$.
\end{abstract}

Keywords: Correlation, Mathematic abiliy, Physics 


\section{Pendahuluan}

Fisika merupakan salah satu cabang ilmu pengetahuan alam yang mempelajari fenomena alam, yang mencakup materi, gerak serta energi yang menyertainya (Kereh, dkk 2014). Menurut Serway, et al (2009), Fisika adalah ilmu pengetahuan tentang dunia fisik yang paling fundamental, mempelajari prinsip-prinsip dasar dari alam semesta. Fisika juga sangat erat kaitannya dengan ilmu pengetahuan yang lain seperti Astronomi, Geologi, Kimia dan Biologi (Awodun, et $a l$, 2013). Hampir semua aspek kehidupan berkaitan dengan Fisika, mulai dari keteknikan (engineer) sampai Matematika, Biologi, dan Kimia. Fisika juga menjadi salah satu matakuliah wajib universitas untuk mahasiswa fakultas teknik, kedokteran, dan ilmu terapan yang lain. Sehingga Fisika juga sangatlah penting dipelajari oleh calon pendidik IPA.

Dasar Zat, Panas dan Optika merupakan salah satu mata kuliah wajib Fisika di program studi Pendidikan IPA. Mata kuliah ini mengkaji tentang struktur materi, mekanika fluida, ilmu panas, termodinamika dan optika geometri. Bahasan-bahasan tersebut membutuhkan kemahiran matematika dalam memahami dan menyelesaikan semua persoalan, seperti kemampuan menghitung, kemampuan proses aljabar, kemampuan trigonometri, kemampuan mengukur dan kemampuan menerjemahkan tabel dan grafik (Awodun, et. al, 2013). Namun, masih banyak mahasiswa yang merasa kesulitan mempelajari Fisika, hal ini terbukti dengan keluhan mereka yang mengatakan saya tidak bisa mengerjakan soal-soal ujian dengan baik karena tidak paham dengan maksud dari soalnya. Penyebab kesulitan mahasiswa adalah kemampuan matematika yang rendah dan kurang pahamnya konsep fisika yang diperoleh selama pembelajaran (Munawaroh, 2015). Selain itu sulitnya Fisika menurut Ornek, et al (2008) karena penyajian konten yang berbeda-beda pada waktu yang sama seperti praktikum, persamaan dan perhitungan, grafik, dan penjelasan konsep.

Menurut Ornek, et al (2008) mengklasifikasikan bahwa kesulitan dalam fisika dikarenakan (1) motivasi dan minat; (2) kurang belajar; (3)tidak membaca buku teks; (4) tidak melengkapi latihan soal; (5) kurangnya latihan soal yang bervariasi; (6) hanya mengerjakan soal-soal yang ditugaskan; (7) tidak mengerjakan PR dirumah; (8) kurangnya pengalaman; (9) kurangnya pemahaman konsep fisika dan (10) kurangnya kemampuan matematika yang baik.

Penelitian mengenai korelasi kemampuan matematika dengan fisika telah banyak dilakukan, diantaranya oleh Hudson \& McIntire (1977) menyatakan bahwa kemampuan aljabar dan trigonometri berkorelasi positif dengan kemampuan fisika dasar, Meltzer (2002) juga menyatakan bahwa kemampuan matematika siswa berkorelasi positif terhadap ujian Fisika Dasar, Awodun, et.al (2013) menyatakan bahwa enam kemampuan matematika berpengaruh terhadap kemampuan fisika, jika kemampuan matematikanya bagus maka kemampuan fisikanya juga bagus. Kereh, dkk (2014), Haryadi, dkk (2015) dan Li, et al (2002) menyatakan hal yang senada yaitu bahwa ada korelasi positif antara nilai matematika dengan fisika.

Dari penelitian-penelitian tersebut menjadi dasar untuk meneliti tentang bagaimana korelasi nilai matematika dan fisika di program studi Pendidikan IPA. Harapannya dengan penelitian ini, akan ada perbaikan kedepan mengenai pembelajaran matematika dan fisika yang terintegrasi serta menyenangkan bagi mahasiswa. 


\section{Metode Penelitian}

Penelitian ini menggunakan jenis kuantitatif deskriptif. Subjek penelitian adalah mahasiswa program studi Pendidikan IPA FIP UTM angkatan 2015/2016. Teknik pengumpulan data dalam penelitian ini adalah melalui dokumentasi yang diperoleh pada bagian akademik FIP Universitas Trunojoyo Madura. Data yang diperoleh terkait penelitian yaitu nama, nomor induk mahasiswa, serta nilai mata kuliah Matematika I, Matematika II dan Dasar Zat, Panas dan Optika. Data yang diperoleh selanjutnya dianalisis korelasinya menggunakan rumus korelasi Pearson dengan harga $r_{x y}$ pada $\alpha=0,005$. Perhitungan nilai korelasi dimaksudkan untuk menguji hubungan antara nilai Matematika I dan Matematika II dengan Dasar Zat, Panas dan Optika.

\section{Hasil Penelitian dan Pembahasan}

Mata kuliah Matematika I membahas tentang matriks, vektor, fungsi, limit fungsi dan diferensiasi. Untuk mata kuliah Matematika II membahas tentang integral serta aplikasinya. Sedangkan mata kuliah Dasar zat, Panas dan Optika membahas tentang struktur materi, mekanika fluida, panas, termodinamika dan optika geometri. Dari materi Fisika tersebut membutuhkan dasar matematika yaitu aljabar, diferensial (turunan), integral dan trigonometri.

Sampel yang digunakan adalah mahasiswa semester 4 yang sudah mendapatkan mata kuliah Matematika I, Matematika II dan Dasar Zat, Panas dan Optika. Nilai rata-rata Matematika I, Matematika II dan Dasar Zat, Panas dan Optika dapat dilihat pada Tabel 1. Dari tabel 1 terlihat bahwa rata-rata nilai Matematika I tertinggi adalah kelas B sebesar 74,27, rata-rata nilai Matematika II tertinggi adalah kelas B sebesar 76,49, dan rata-rata nilai Dasar Zat, Panas dan Optika tertinggi adalah kelas $\mathrm{C}$ sebesar 76,74. Nilai Matematika I untuk kelas B dengan rata-rata tertinggi ditunjukkan oleh Gambar 1, nilai Matematika II untuk kelas B dengan rata-rata tertinggi ditunjukkan oleh Gambar 2 dan nilai Dasar zat, Panas dan Optika dapat dilihat pada Gambar 3.

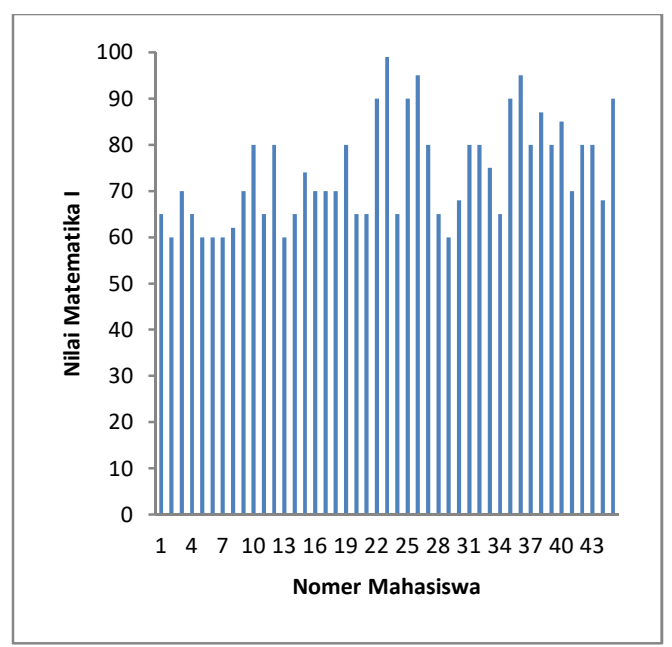

Gambar 1 . Grafik nilai Matematika I untuk kelas $\mathrm{B}$ dengan rata-rata 74,27

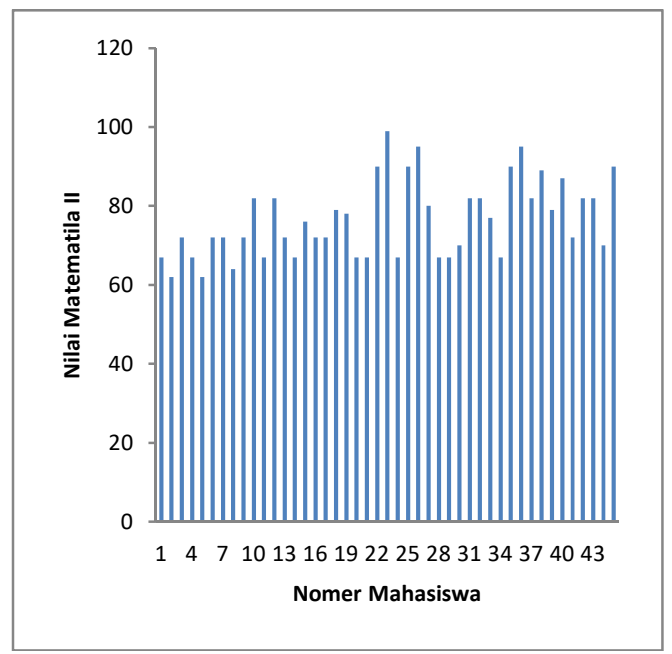

Gambar 2. Grafik nilai Matematika II untuk kelas B dengan rata-rata 76,49 


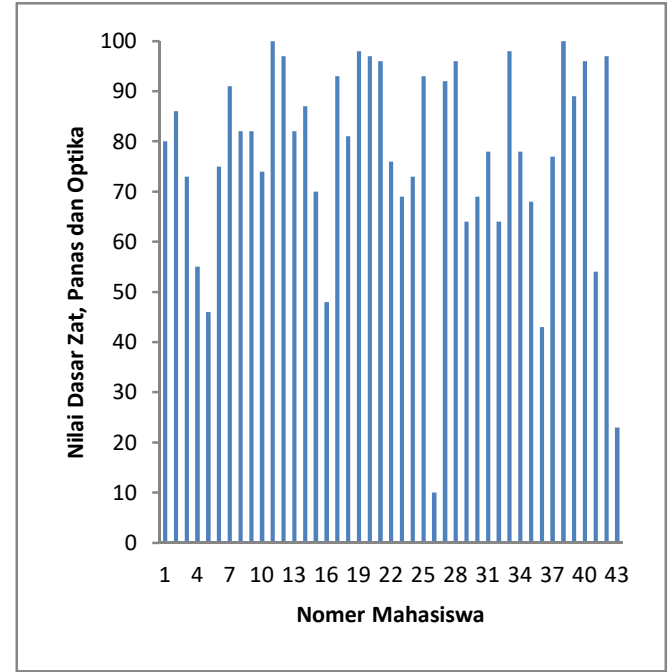

Gambar 3. Grafik nilai Dasar zat, panas dan Optika untuk kelas $\mathrm{C}$ dengan rata-rata 76,74

Tabel 1. Rekapitulasi Rerata untuk nilai Matematika I, Matematika II dan Dasar Zat, Panas dan Optika

\begin{tabular}{cccc}
\hline Kelas & $\begin{array}{c}\text { Rata-rata } \\
\text { Nilai } \\
\text { Matemati } \\
\text { ka I }\end{array}$ & $\begin{array}{c}\text { Rata-rata } \\
\text { Nilai } \\
\text { Matemati } \\
\text { ka II }\end{array}$ & $\begin{array}{c}\text { Rata-rata Nilai } \\
\text { Dasar Zat, } \\
\text { Panas dan } \\
\text { Optika }\end{array}$ \\
\hline $\mathrm{A}$ & 70,23 & 72,88 & 62,23 \\
$\mathrm{~B}$ & 74,27 & 76,49 & 59,55 \\
$\mathrm{C}$ & 71,91 & 75,19 & 76,74 \\
\hline
\end{tabular}

Gambar 4 adalah plotting nilai Matematika I dan Dasar zat, Panas dan Optika. Sedangkan plotting nilai Matematika II dan Dasar zat, Panas dan Optika dapat dilihat pada gambar 5. Dari grafik pada Gambar 1 dan 2 menunjukkan bahwa ada korelasi positif antara penguasaan Matematika I terhadap penguasaan Dasar zat, Panas dan Optika dan penguasaan Matematika II terhadap Dasar zat, Panas dan Optika. Indeks korelasi penguasaan pada materi tersebut dapat dilihat pada Tabel 2 dan 3.
e-ISSN: 2527-7634

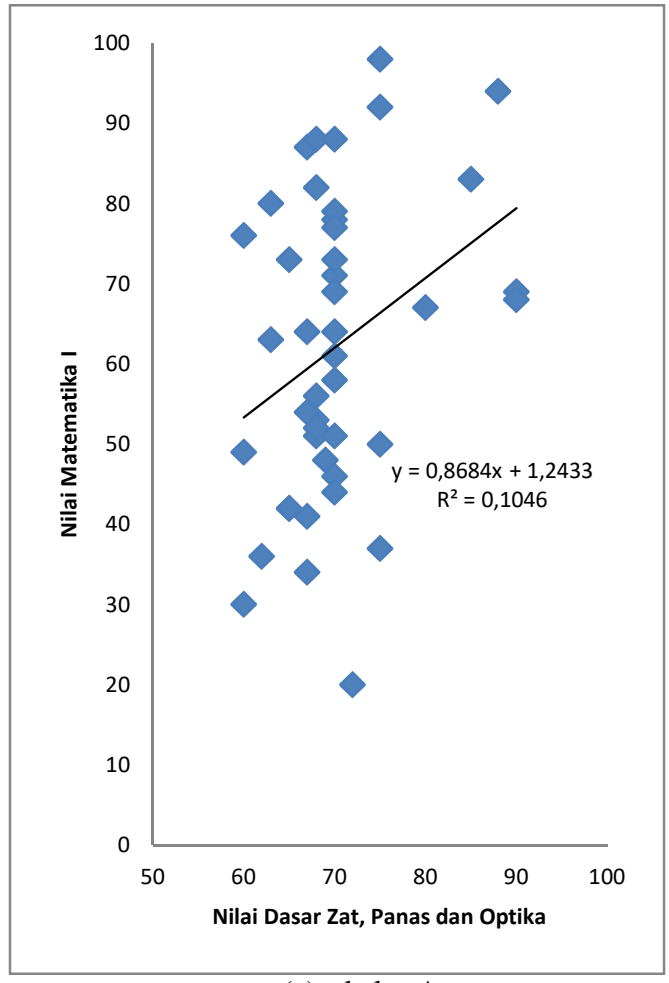

(a) kelas $\mathrm{A}$

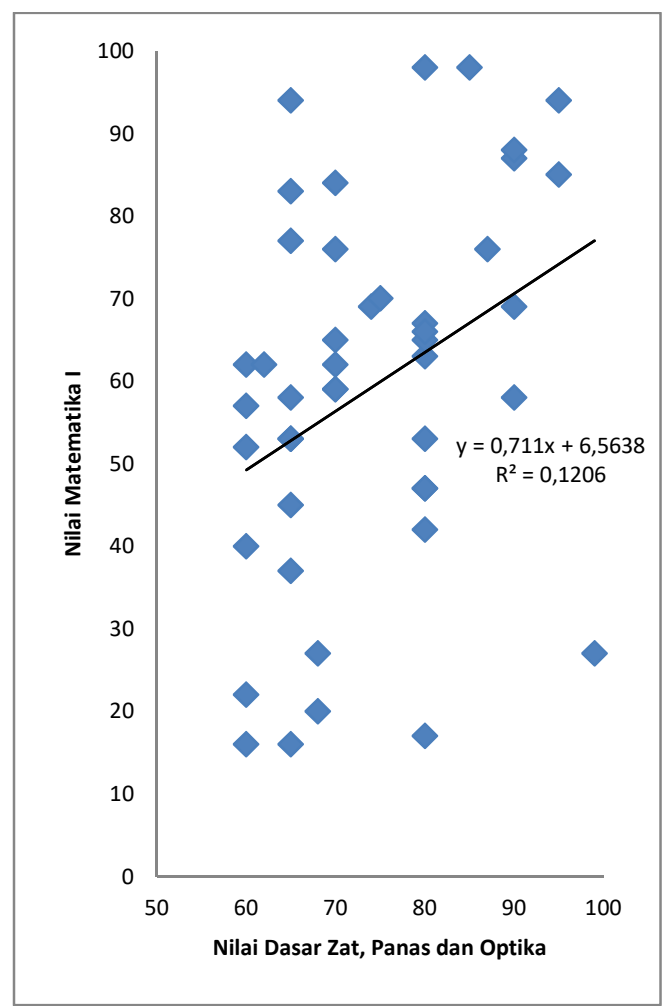

(b) kelas B 


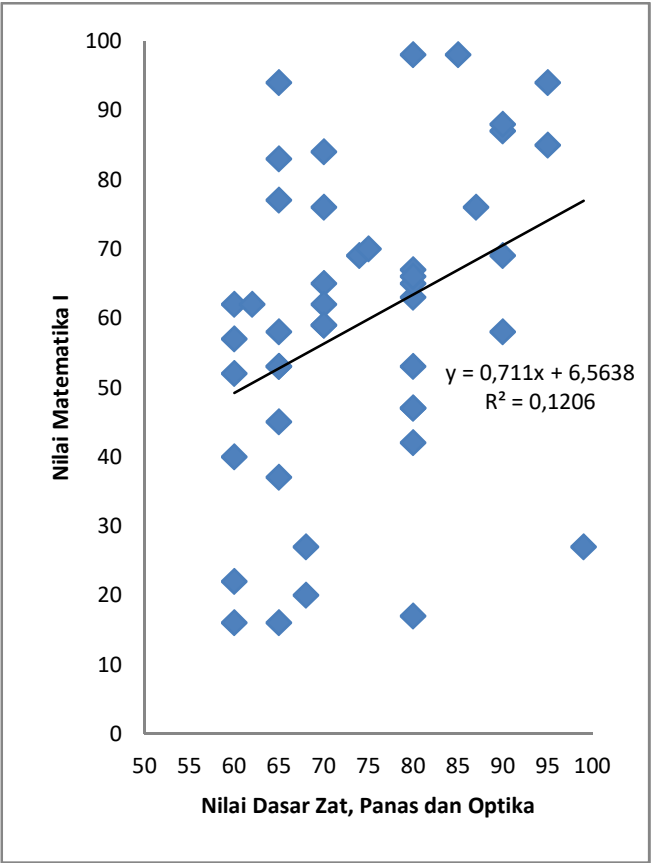

(c) kelas C

Gambar 4. Plotting nilai Matematika I dan nilai Dasar Zat, Panas dan Optika (a) kelas A,

(b) kelas B dan (c) kelas C

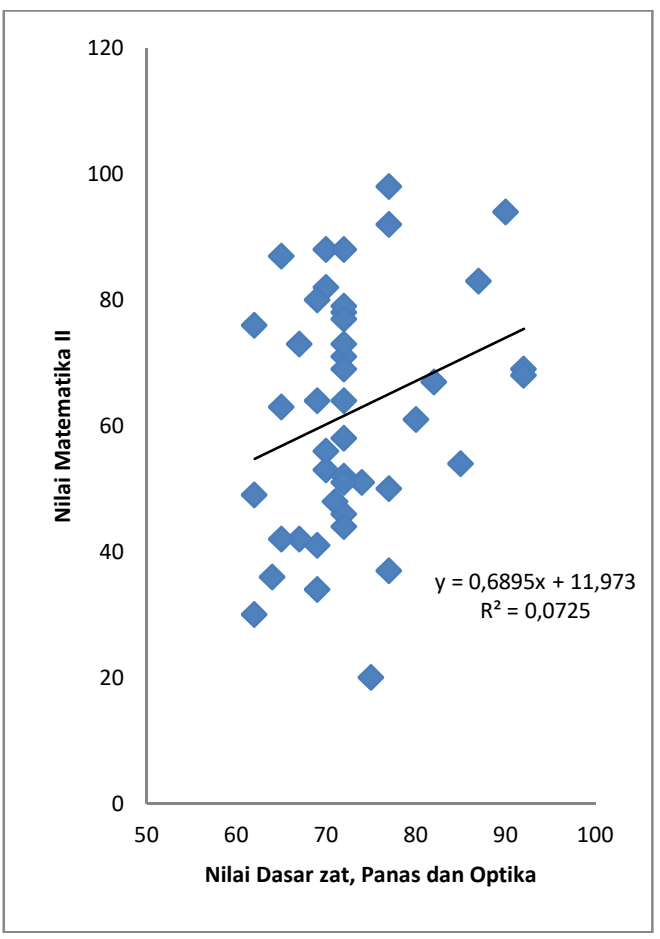

(a) kelas A

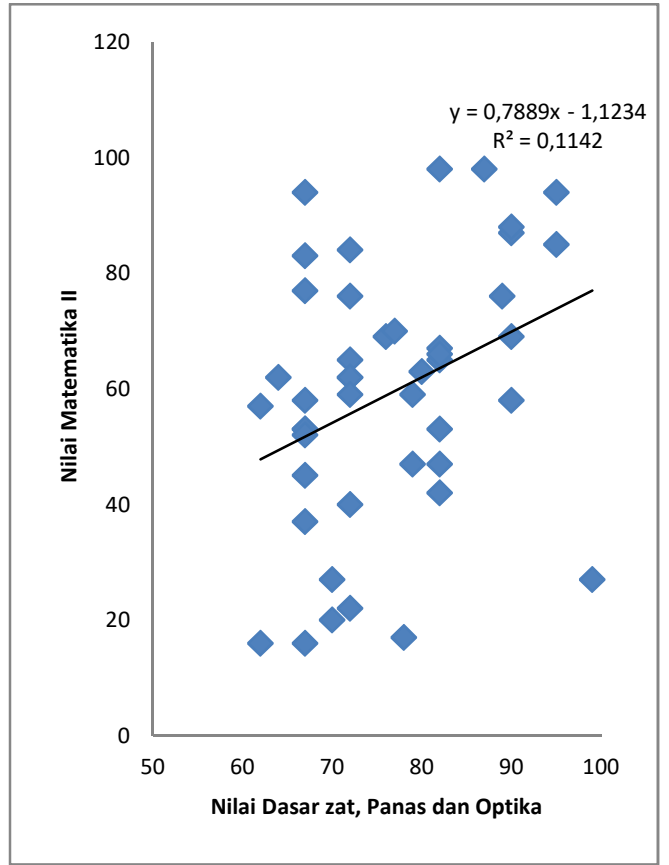

(b) kelas B

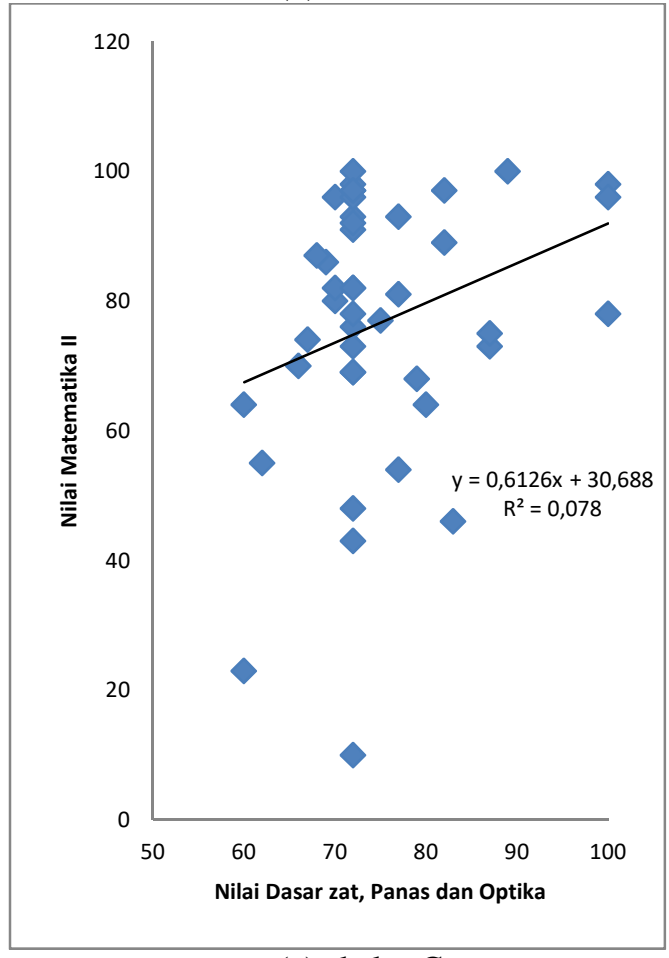

(c) kelas C

Gambar 5. Plotting nilai Matematika II dan nilai Dasar Zat, Panas dan Optika (a) kelas A, (b) kelas B dan (c) kelas C 
Tabel 2. Korelasi Nilai Matematika I dan Dasar Zat, Panas dan Optika

\begin{tabular}{cc}
\hline Kelas & $\boldsymbol{R}$ \\
\hline A & 0,52 \\
B & 0,34 \\
C & 0,23 \\
\hline
\end{tabular}

Tabel 3. Korelasi Nilai Matematika II dan Dasar Zat, Panas dan Optika

\begin{tabular}{cc}
\hline Kelas & $\boldsymbol{R}$ \\
\hline A & 0,27 \\
B & 0,34 \\
C & 0,28 \\
\hline
\end{tabular}

Berdasarkan Gambar 4 dan Tabel 2 dapat dilihat bahwa penguasaan Matematika I terhadap penguasaan Dasar zat, Panas dan Optika berkorelasi positif, dengan indeks korelasi tertinggi pada kelas A yaitu sebesar 0,52. Sedangkan penguasaan Matematika II terhadap penguasaan Dasar zat, Panas dan Optika juga berkorelasi positif, dengan indeks korelasi tertinggi pada kelas B sebesar 0,34 . Indeks korelasi pada penelitian ini hampir sama dengan penelitian Usoro, et al (2008), Shrestha and Shields (2008) Indeks korelasi pada penelitian ini lebih rendah dari penelitian Kereh, dkk (2014) yaitu sebesar 0,75 untuk kelas eksperimen dan sebesar 0,73 untuk kelas kontrol. Hal ini karena pada penelitian Kereh, dkk memberikan perlakuan pada kelas eksperimen dengan model blended learning. Sedangkan pada penelitian ini hanya dengan teknik dokumentasi dengan kelas konvensional. Indeks korelasi pada penelitian ini juga lebih rendah dari penelitian Awodun dan OJO (2013) yaitu sebesar 0,93, Hudson dan McIntire (1976) sebesar 0,618 .

Indeks korelasi positif menunjukkan bahwa penguasaan Matematika sangat berpengaruh terhadap hasil belajar Fisika (Dasar zat, Panas dan Optika). Hal ini senada dengan penelitian sebelumnya yaitu oleh Kereh, dkk (2014), Meltzer (2002), Hudson dan McIntire (1976), Haryadi dan Pujiastuti (2015),
Shrestha and Shields (2007), Usoro, et al ( 2008) dan Li, et al (2002). Beberapa konsep Matematika yang perlu dikuasai agar bisa menguasai Dasar zat, Panas dan Optika yaitu kemampuan aljabar, trigonometri, mengukur dan menginterpretasikan tabel dan grafik.

Kemampuan Matematika yang rendah akan berpengaruh terhadap penyelesaian soal-soalDasar zat, Panas dan Optika. Beberapa kesalahan yang sering dilakukan oleh mahasiswa yaitu dalam proses perhitungan atau menerjemahkan soal. Hal ini terlihat pada hasil ujian mahasiswa, masih ada yang belum mampu menghitung pecahan dan perpangkatan (eksponen). Padahal dalam materi Matematika I sudah di ajarkan. Contoh kesalahan mahasiswa dalam mengerjakan soal Dasar zat, Panas dan Optika dapat dilihat pada Gambar 6 . Selain kemampuan Matematika yang rendah, kesalahan juga sering dilakukan mahasiswa ketika mengerjakan soal adalah kurang teliti dalam menyelesaikan soal, seperti pada Gambar 7. Namun sebaliknya mahasiswa dengan kemampuan matematika yang baik diharapkan penguasaan Fisikanya juga baik, hal ini senada dengan pernyataan Awedun, et al (2013), dan Hudson dan McIntire (1977).

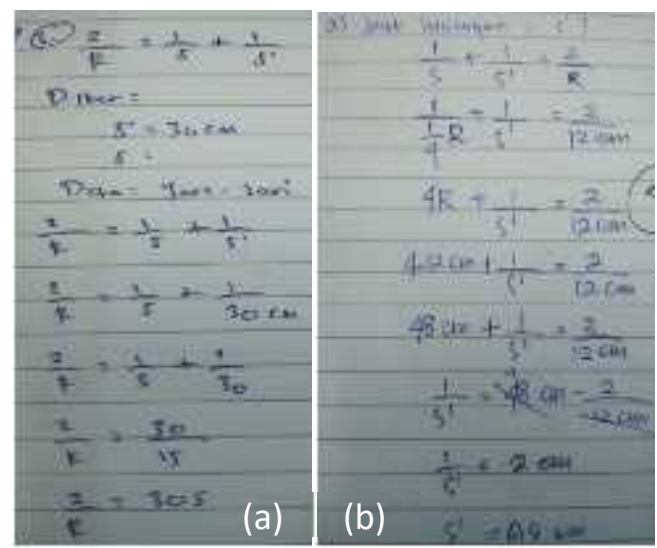


Gambar 6. Kesalahan mahasiswa dalam proses aljabar, (a) dan (b) perhitungan pecahan,
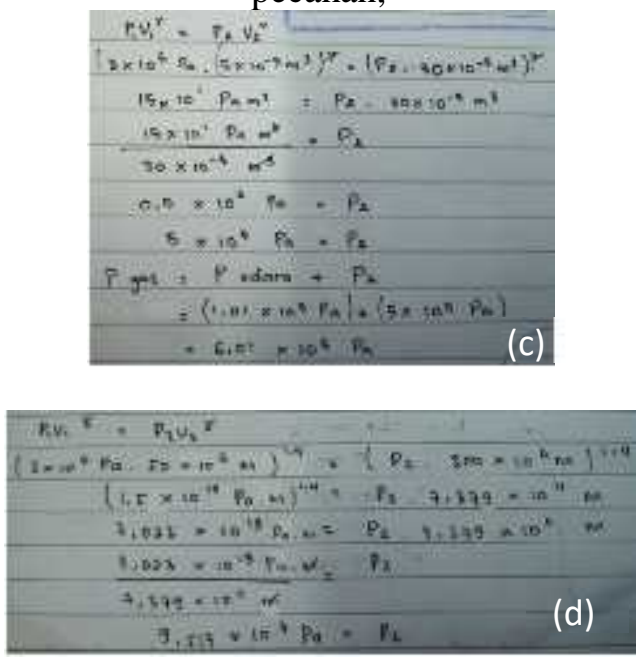

Gambar 7. Kesalahan mahasiswa dalam proses aljabar, (c) dan (d) perhitungan pangkat

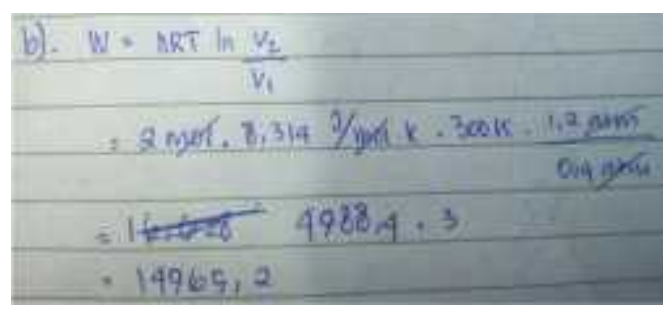

Gambar 8. Contoh kesalahan mahasiswa karena kurang teliti dalam menyelesaikan soal

\section{Kesimpulan dan Saran}

Berdasarkan hasil analisis dan pembahasan diketahui bahwa nilai Matematika I dan Dasar zat, Panas dan Optika berkorelasi positif, dengan indeks korelasi berturut sebesar sebesar 0,52; 0,34 dan 0,23 untuk kelas A, B dan C. Sedangkan . Indeks korelasi antara nilai Matematika II dengan nilai Dasar zat, Panas dan Optika berturut-turut sebesar 0,27; 0,34 dan 0,28 untuk kelas A, B dan C. Hal ini berarti penguasaan Matematika
I dan II berpengaruh terhadap hasil belajar Fisika yaitu Dasar zat, Panas dan Optika.

Kemampuan Matematika yang diperlukan dalam mata kuliah Dasar zat, Panas dan Optik yaitu kemampuan proses aljabar, trigonometri, menerjemahkan tabel dan grafik, dan kemampuan mengukur. Mahasiswa yang mempunyai kemampuan matematika baik maka diharapkan penguasaan Fisikanya juga baik.

\section{Daftar Pustaka}

Awodun, Adebisi O., and OJO, Olanrewaju Adeniyi. 2013. Mathematics Skills as Predictors of Physics Students' Performance in Senior Secondary Schools. International Journal of Science and Research (IJSR), Volume 2 (7), 391-394.

Haryadi, R. dan Pujiastusti, H. 2015. Kemampuan Matematis terhadap Hasil belajar Fisika, Prosiding SKF, 174-177.

Hudson, H. Ti. and McIntire, W. R.. 1977. Correlation Between Mathematical Skills and Success in Physics. American Journal of Physics, Volume 45 (5), 470-471.

Kereh, C.T., Liliasari, T., P.C., and Sabandar, J.. 2014. Korelasi Penguasaan Matematika Dasar dengan Penguasaan Materi Pendahuluan Fisika Inti. Jurnal Pendidikan Fisika Indonesia, Volume 45 (5), 470-471.

Li, Min, Shavelson, Richard J., Kupermintz, Haggai and RuizPrimo, M. A. 2002. On The Relationship Between Mathematics and Science Achievement in The United States. Secondary Analysis of the TIMSS Data, 233-249.

Meltzer, D. E.. 2002. The Relationship Between Mathematics Preparation 
and Conceptual Learning Gains in

Physics: A Possible "Hidden

Variable" in Diagnostic Pretest

Scores. American Journal of

Physics, Volume 70 (12), 12591268.

Munawaroh, F. 2015. Analisis Kesalahan Mahasiswa Pendidikan IPA dalam Menyelesaikan Materi Kinematika. Prosiding Seminar Nasional Fisika. 128-132.

Ornek, F., Robinson, WR., Haugan, MP. 2008. What Makes Physics Difficult?. Interntional Jurnal of Inveromental\&Science Education Vol 1(3), 30-34.

Serway, R. A. dan Jewett, J. W. 2009. Fisika untuk sains dan Teknik. Jakarta: Salemba Teknika

Shrestha, P. P. and Shields, D. R. 2008. Correlating Student Performance in Fundamental of Construction Science Course with Mathematics and Physics Grade Point Average. http://ascpro0.ascweb.org/archives/ cd/2009/paper/CEUE124002009.pd f, diakses 30 Maret 2017.

Usoro, H., Akpan, G.A., and Ukoro, E. A. 2008. Predicting Students' Performances in Physics and Chemistry in The Nigerian Secondary Schools: Implication For Technical Education (A case of Multiple Correlation/Regretion). Halaman 113-122. http://globalacademicgroup.com/jo urnals/the\%20intuition/Predicting\% 20Students\%E2\%80\%99\%20Perfor mance\%20in\%20Mathematics\%20f rom\%20their.pdf, diakses 31 Maret 2017. 